\title{
Assessment of Psychological Problems among Adolescent Females with Burn
}

\section{${ }^{1}$ Asmaa Abdel Rahman Sadek El-nemr, ${ }^{2}$ Maaly Ibrahim EL-malkey, ${ }^{3}$ Shewikare Tawfik EL- Bakry, and ${ }^{4}$ Samah Ramadan Ibrahim}

(1) Nursing Specialist at El-Sinbelawein Centralized Hospital, (2) Professor of Psychiatric and Mental Health Nursing, Faculty of Nursing, Menoufia University, (3) Assist. Prof of Psychiatry, Faculty of Medicine, Benha University and, (4) Lecturer of Psychiatric and Mental Health Nursing, Faculty of Nursing, Benha University

\begin{abstract}
Background: Burns are acute unpredictable and devastating forms of trauma that affect both physical and psychological health of adolescent females with burn as social anxiety, depression and posttraumatic stress disorder. The aim of the study was to investigate psychological problems among adolescent females with burn. Research design: Descriptive correlational design was utilized to achieve this aim. Setting: Burn Unit of Benha Teaching Hospital in Benha City. Sample: A convenience sample of 100 adolescent females who were admitted to burn unit from above mentioned setting. Tools: Four tools were used in this study: A Structured interviewing questionnaire sheet to assess personal data and clinical data, Social Phobia Inventory, Posttraumatic Stress Disorder Checklist and Burn Depression Checklist were used to assess psychological problems. Results: The findings revealed that the mean age of adolescent females with burn was $15.8 \pm 1.84$ years, the majority of the studied sample had social phobia ranged from sever to mild. Majority had high level of posttraumatic stress disorder. The entire studied sample had depression ranged from mild to severe. There was positive significant correlation between social phobia and posttraumatic stress disorder, there was positive significant correlation between depression and posttraumatic stress disorder, as well as there was positive significant correlation between depression and social phobia. Conclusion: Burn have great negative effect on psychological status of female adolescence. Recommendation: The study recommended that psycho educational nursing program focus on stress management technique, problem solving skills and assertiveness should be developed and implemented to all burn patients to help them to manage psychological effects that result from burn injury in a constructive way.
\end{abstract}

Key words: Adolescent, Burn, Females, Psychological problems

\section{Introduction:}

Adolescence is a stage of increased awareness and the interest of self-reflection and bodily cues including appearance and evaluation of the body. Body image during adolescence is an integral part of self-concept that involves how we think, perceive and act toward our body. Adolescent female who depart from socially determined norms of ideals or attractiveness are usually vulnerable to body dissatisfaction. Any abnormal changes in adolescent females' body shape and appearance lead to physical, social and psychological problems. In fact, perception of the body about abnormal appearance especially the beauty of the face is a major factor affecting selfawareness after burn injury (Hoffmann\&Warschburger, 2018).

Burn injury is the most common serious emergency medical condition and devastating forms of trauma which has negative impact on the victims. Severe contractures and scarring 
following burn injuries greatly affect burn victims, they may feel loss of self as burn victims are often depend on family members and friends which lead to increase economic burden (Agbenorku et al., 2016). Also burn injury affects psychological health of burn victims such as depression, sleeping disorders, low quality of life, post-traumatic stress disorder and social anxiety (Waqas et al., 2018).

Social anxiety is an emotional experience occurs in response to perceived threat of negative evaluation from others before, during and after exposure to social situation. Burn victims fear from dealing with others. When social anxiety disorder reaches a high level, it leads to impairment of daily functioning associated with emotional distress (Heeren et al., 2014). Altered physical condition of burn patients is a barrier for interacting with other members in society, also causes feeling of inferiority that can lead to psychological problems as discouragement, grief, loss of social network, shame and depression (Din et al., 2015).

Depressive symptoms are the most common psychiatric disorder reported in burn injury patients. Depression in burn victims has a Varity of psychological disorders as low mood, loss of pleasure or interest, inability to concentrate, guilt feeling, change in sleeping pattern, suicide, appetite changes, body weight changes, feeling of hopelessness and helplessness, poor quality of life, self-dislike and feeling of dissatisfactions that lead to impairment of daily functioning and disturbed life of burn victims. The symptoms present for two weeks to several months. Besides, many burn victims after burn injury manifested symptoms of posttraumatic stress disorder (Wiechman et al., 2016).

Posttraumatic stress disorder is developed after exposure to traumatic experience as burn injury. Symptoms of posttraumatic stress disorder include nightmares of trauma, flashbacks, hyper vigilance, intrusive thoughts, avoidance of reminders of trauma and disturbed sleeping pattern. Post-traumatic stress disorder is a condition that develops after experiencing a shocking, scary or dangerous event. All these disturbances may lead to interpersonal struggle accompanied by comorbid secondary decoders as depression and anxiety disorders, which lead to impairment of daily life and affect social life (Burns, 2016).

The nurse should encourage the patient to socialize and to make social interaction with the surrounding. The patient should be advised that problems can be treated and it will diminish over the time. It is important for burn patients especially those with depressive or posttraumatic symptoms to follow up with psychotherapeutic intervention, also exposure therapy, social skill training and cognitive behavioral therapy should be encouraged (Akarsu et al., 2017).

\section{Significance of the problem:}

Burn injuries are a global public health problem with significant high mortality and morbidity rates. In Egypt burn injuries estimated to be approximately one in every thousand. It also reported that burn constitute $12.5 \%$ of all hospital admission with $48 \%$ of the admitted burn patients suffering from complications (Fathy, 2014). In Benha Teaching Hospital documented the admitted 
number of burn patients in the year of 2015 was 245, in 2016 was 250 and in the year of 2017 was 346 patients (Statistical Department of Benha Teaching Hospital, 2017). According to recent study by Manzoor et al (2016) the pattern of psychological morbidity after burn injury demonstrated that, $22,2 \%$ had major depressive disorder, $32,2 \%$ had generalized anxiety disorder, $16,6 \%$ acute stress disorder, $14,4 \%$ post-traumatic stress disorder, 8,8\% panic disorder without agoraphobia and $5,5 \%$ panic disorder with agoraphobia.

Therefore, it is important to assess psychological problems of female burn adolescent such as depression, social anxiety and post-traumatic stress disorder.

\section{Theoretical and operational definition:-}

Psychological problems defined
theoretically as being characterized by
clinically significant disturbance in individual's cognition, emotional regulation or behavior reflects dysfunction in the psychological, biological or developmental process underlying mental functioning, psychological disorders are usually associated with significant distress in social, occupational or other important functioning (American Psychiatric Association, 2013). In the present study it can be defined by the mean score of social anxiety which reflect person overwhelming concern about being judged or evaluated negatively by others in exposure to social situation leading to avoidance and social withdrawal measured by (Conner et al., 2000). Also the mean score of post-traumatic stress disorder which reflect condition of individuals that develop following exposure to extremely traumatic events as distressing, intrusive memories, nightmares of the trauma, irritability, hyper-vigilance, difficulty of sleeping, poor concentration and emotional withdrawal measured by (Weathers et al., 1994). The mean score of depressive disorder symptoms as loss of interest or pleasure, sadness, low self-worth, disturbed sleep or appetite, feeling of tiredness, poor concentration and suicide urges those symptoms impair individuals ability to function at work, school or cope with daily life measured by (David, 1989).

\section{Aim of the study:}

This study aims to investigate psychological problems among adolescent females with burn.

\section{Research Question:}

What are the psychological problems among adolescent females with burn?

\section{Subject and Method}

\section{Research design:}

Descriptive correlational design was utilized to achieve the aim of the study.

\section{Setting:}

The study was conducted at Burn unit of Benha Teaching Hospital in Benha City. It's the most common hospital specialized with the unit for burn. It is an educational hospital for training nursing and medical students. The burn unit consists of six rooms. It includes 19 beds, there is another two rooms for dressing wound. All beds are occupied all the time. The burn unit receives patients from all over country in the level of Qalubeia Governorate. 


\section{Sample:}

A convenience sample of 100 adolescent females admitted to burn unit with burn at Benha Teaching Hospital at the time of the research within six month who fulfilled the following inclusion and exclusion criteria.

\section{Inclusion criteria:}

1.Adolescent females (13-19) years old.

2.Able to talk and express themselves verbally.

3.Patients with second and third degree of burn.

4.Willingness to participate in the study.

\section{Exclusion criteria:}

1. Patients in coma.

2. Psychiatric and mental illness.

3. Chronic physical illness.

\section{Tools:}

Four tools were used for data collection:

\section{Tool one: A structured interviewing questionnaire sheet:-}

The investigator developed this tool. It divided into two parts.

Part (I): To assess personal data as (age, level of education, occupation, family income, number of family members).

Part (II): To assess clinical data as (cause of burn, degree of burn, the circumstances of the fire, site of burn, burn rate, injuries associated with burn, an infection of wound).

\section{Second tool: Social phobia Inventory (SPIN):}

Social phobia Inventory (SPIN), it was designed by Conner et al., (2000) to measure social phobia disorder (fear-avoidance- physiological arousal). It consisted of 17 items where fear consisted of 7 items as afraid of people in authority, scaring from parties and social events, scaring from criticism, fear of embarrassment, fear from talking to strangers, fear from doing things when people might be watching and fear from embarrassed or looking stupid.

Avoidance consisted of 6 items as avoiding talking to people who don't know, avoiding going to parties, avoiding activities in which being under the center of attention, avoid having to give speeches, doing anything to avoid being criticized and avoid speaking to anyone in authority.

Physiological arousal consisted of 4 items as blushing in front of people, sweating in front of people that cause her distress, heart palpitation when being around people and trembling or shaking in front of others.

Rating 0-4 where 0 indicate not at all, 1 little bit, 2 somewhat, 3 very much, 4 extremely.

\section{Scoring system:-}

Scoring system of social phobia range from 0-68 where less than (20) means no social anxiety.

- $\quad$ From (21) to (30) mild degree of social phobia.

- From (31) to (40) moderate degree of social phobia.

- From (41) to (50) severe degree of social phobia.

- (51) Or more indicate severe degree of social phobia. 


\section{Third tool:-Post-Traumatic Stress Disorder Checklist (PCL-C)}

Post-Traumatic Stress Disorder Checklist Civillian Version (PCL-C). It was adopted by Weathers et al., (1994). It was designed to measure stress disorder after traumatic events. It consisted of 17 items as, repeated memories, thoughts or images of stressful experience, repeated disturbing dreams, suddenly acting or feeling as stressful experience where happing again, feeling very upset when something reminded her of stressful experience, having physical reaction as heart rate pounding, trouble breathing and sweating, avoiding thinking about stressful experience, avoiding activities or situations that reminded her to stressful experience, trouble remembering important parts of stressful experience, loss of interest in activities, feeling distant or cut off from other people, feeling emotionally numb or unable to have love feeling for those close to her, feeling as future will be short, trouble falling or staying asleep, feeling irritable or having angry, having difficulty in concentration, being super alert and feeling jumpy or easily startled . Rating 1-5 where 1 indicates not at all, 2 a little bite, 3 moderately, 4 a quite bit, 5 extremely.

\section{Scoring system:-}

- $\quad$ Scoring system range from 17-85.

- $\quad$ The score from (17) to (29) shows little to no severity of post-traumatic stress disorder.

- From (30) to (44) moderate degree of post-traumatic stress disorder.

- From (45) to (85) shows high severity of post-traumatic stress disorder.

Fourth tool: Burn Depression Checklist (BDCL) (1989) :-
Burn Depression Checklist (BDCL) was adopted by David (1989). It was designed to measure depression of burn patients, it consists of 25 item .It was divided to four-sub scale:-

\section{Subscale I Thoughts and Feeling:-}

It consisted of 10 items, it included patients thought and feeling focusing on feeling sad or down in the dumps, feeling un happy or blue, crying spells or tearfulness, feeling discouraged, feeling hopeless, low self-esteem, feeling worthless or feeling hopeless, guilt or shame, criticizing herself or blame others and difficulty in making decisions.

\section{Subscale II Activities and Personal Relationships:-}

It consisted of 7 items, it included patients activities and personal relationships focusing on loss of interest in family, friends or colleagues, loneliness, spending less time with family or friends, loss of motivation, loss of interest in work or other activities, avoiding work or other activities and loss of pleasure or satisfaction in life.

\section{Subscale III Physical Symptoms:-}

It consisted of 5 items, it included patients physical symptoms as feeling tired, difficulty in sleeping or sleeping too much, decreased or increased appetite, loss of interest in sex in married females and worrying about health.

\section{Subscale IV Suicidal Urges:-}

It consisted of 3 items; it included patients' suicidal urges as suicidal thoughts, like to end the life and suicidal planning. 
All subscales were rated from 0-4 where 0 indicate not at all, 1 sometimes, 2 moderately, 3 a lot, 4 extremely.

\section{Scoring system:-}

Scoring system ranges from $0-100$

Where (0) to (5) means no depression From (6) to (10) normal but unhappy From (11) to (25) mild depression From (26) to (50) moderate depression From (51) to (75) severe depression From (76) to (100) extreme depression.

\section{Pilot study:}

A pilot study was taken after the development of the tools and before starting data collection. It was conducted on 10 adolescent females with burn for two weeks at Benha Teaching Hospital in Burn Unit, using tools (1), (2) and (3). The purpose of the pilot study was to test the clarity, applicability and feasibility of the tools. In addition to, it served to estimate the approximate time needed for interviewing the patients as well as to find any problems that might interfere with data collection. After obtaining results of pilot study, no modifications of tools were done. A final format was developed under the guidance of supervisors. Those patients were excluded from the actual study.

\section{Content Validity of the tools:}

Tools were provided to a jury of 5 experts in the Psychiatric and Mental Health Field. Tools were checked for the clarity, relevancy, comprehensiveness and applicability of the questions, the tool proved to be valid according to their opinions, no modifications were done.

\section{Reliability of the tools:-}

It was applied by the researcher for testing the internal consistency of the tool by administration of the same tools to the same subjects under similar condition on one occasion. Answer from repeated testing were compared (test - retest reliability) the tools revealed strongly reliable at .90 for Social Anxiety Inventory, 87 for Post-Traumatic Stress Disorder Checklist and ,91 for Burn Depression Checklist.

\section{Ethical consideration:}

The subjects were informed about the nature and aim of the study. They were assured that the information would remain confidential and the results would be used for the research purpose only. They were given an opportunity to refuse to participate and they could withdraw at any time from the research. The investigator emphasized that participation in the study was voluntary and anonymity will be estimated. After full explanation about the aim of the study, oral consent was taken before participation in the study.

\section{Field work:}

Before data collected an official letter was addressed from Faculty of Nursing Benha University to the Director of Benha Teaching Hospital at the above mentioned setting for requesting their permission and cooperation to conduct the study. All of the authorized personnel provided needed information about the purpose and the importance of the study. The adolescent females with burn who fit the inclusion and exclusion criteria were approached by the investigator to fill the questionnaire, The investigator started data collection by introducing herself to the 


\section{Assessment of Psychological Problems among Adolescent Females with Burn}

participant. Oral consent was obtained from each participant. Then a brief description about the purpose of the study and the type of questionnaire required for filling was given to each participant.

The investigator visited Benha Teaching Hospital at Burn Unit from 9 a.m to 1p.m two days per week (Sunday \& Thursday). Data collection was done through interviewing with (3 to 4) \day of adolescent females with burn at Benha Teaching Hospital in department of burn; each interview lasted for 15-25 minutes depending on the response of the interviewer. Data was collected throughout six months from (February 2018) to (July 2018).

\section{Statistical Analysis:-}

Data collected from the study were coded, revised and entered using PC. Data entry and statistical analysis were done using the statistical package for social science (SPSS) version 20, data were presented using descriptive statistics in the form of frequencies and percentage for qualitative variables, standard deviation and mean for quantitative variables. Qualitative variables were compared by using the chi-square test and correlation coefficient was used to measure the strength and direction of the correlation between variables. A statistical significant level value was considered if $\mathrm{P}$ value was $<0.05$. The highly significant level value when $P$ value $<0.001$. While $\mathrm{P}$ value of $>0.05$ indicated nonsignificant.

\section{Results:-}

Table (1) shows that, more than one third of the studied sample $(40 \%)$ were at the age between
13-15 with the mean age $15.8 \pm 1.84$. More than one quarter $(28 \%)$ were reading and writing. More than two thirds (69\%) of them were not working and around half (47\%) of them had not enough family income.

Table (2) this table showed that, more than two thirds $(70 \%)$ of the studied sample their burn were from fire-flame. All of the circumstances of the fire $(100 \%)$ were accidents, more than two third $(71 \%)$ of the studied sample had third degree of burn, more than one quarter $(29 \%)$ had second degree of burn, more than two fifth $(41 \%)$ of them had moderate degree of burn rate.

Figure (1) this figure reveals that, near to one third of the studied sample (30\%-29\%) respectively had sever and mild degree of social phobia and more than one quarter $(27 \%)$ of them have moderate degree of social phobia.

Figure (2) this figure illustrates that the majority of the studied sample (82\%) had high level of posttraumatic stress disorder, while less than one fifth (18\%) had moderate degree of posttraumatic stress disorder.

Figure (3) this figure illustrates that near to half $(47 \%)$ of the studied sample had moderate degree of depression, nearly one-third (32\%) of them had severe depression, compared to only (19\%) had mild depression.

Table (3) this table reveals that, there was positive significant correlation between social phobia with both of depression and posttraumatic stress at $\mathrm{r}=0.93$ and 0.91 . Also, there was positive correlation between depression and posttraumatic stress disorder at $\mathrm{r}=0.92$. 
Table (4) this table shows that there were highly significant positive correlations between degree of burn and both of social phobia, posttraumatic stress disorder and depression. While there was negative significant correlation between degree of burn and level of education. There was highly negative significant correlation between income and both of social phobia, posttraumatic stress disorder and depression. There were negative significant correlations between level of education and both of social phobia, posttraumatic stress disorder and depression. There were highly significant positive correlations between depression and both of social phobia and posttraumatic stress disorder. 
Table (1): Frequency Distribution of Socio-demographic Characteristics of the Studied Sample $(\mathrm{N}=\mathbf{1 0 0})$.

\begin{tabular}{|c|c|c|}
\hline Socio-demographic characteristics & No & $\%$ \\
\hline \multicolumn{3}{|l|}{ Age } \\
\hline $13-15$ & 40 & 40.0 \\
\hline$>15-17$ & 34 & 34.0 \\
\hline$>17-19$ & 26 & 26.0 \\
\hline Mean \pm SD & & \\
\hline \multicolumn{3}{|l|}{ Level of education } \\
\hline Illiterate & 10 & 10.0 \\
\hline Read and write & 28 & 28.0 \\
\hline $\begin{array}{l}\text { Basic education (elementary- } \\
\text { preparatory) }\end{array}$ & 18 & 18.0 \\
\hline Secondary education & 21 & 21.0 \\
\hline University education & 23 & 23.0 \\
\hline \multicolumn{3}{|l|}{ Occupation } \\
\hline Not working & 69 & 69.0 \\
\hline Working & 31 & 31.0 \\
\hline \multicolumn{3}{|l|}{ Family income } \\
\hline Not enough & 47 & 47.0 \\
\hline Enough & 46 & 46.0 \\
\hline Enough and increasing & 7 & 7.0 \\
\hline \multicolumn{3}{|l|}{ Family Number } \\
\hline $3-4$ & 59 & 59.0 \\
\hline $5-6$ & 34 & 34.0 \\
\hline A lot of 6 & 7 & 7.0 \\
\hline
\end{tabular}


Table (2): Frequency Distribution of Clinical Data of the Studied Sample (N=100).

\begin{tabular}{|l|c|c|}
\hline Clinical data & No & $\%$ \\
\hline \hline Cause of burning & 70 & 70.0 \\
\hline \hline Fire-flame & 16 & 16.0 \\
\hline Liquid-watermelon & 3 & 3.0 \\
\hline Electricity & 11 & 11.0 \\
\hline Chemical liquid & \multicolumn{2}{|c|}{} \\
\hline \hline The circumstances of the fire & 100 & 100.0 \\
\hline \hline Accident & \multicolumn{2}{|l|}{} \\
\hline \hline Degree of burn & 29 & 29.0 \\
\hline \hline Second degree & 71 & 71.0 \\
\hline Third degree & \multicolumn{2}{|l|}{} \\
\hline \hline Burn rate & 27 & 27.0 \\
\hline \hline Mild & 41 & 41.0 \\
\hline Moderate & 32 & 32.0 \\
\hline Sever & \\
\hline
\end{tabular}



Figure (1): Frequency Distribution of Social Phobia among the Studied Patients $(\mathrm{N}=100)$. 


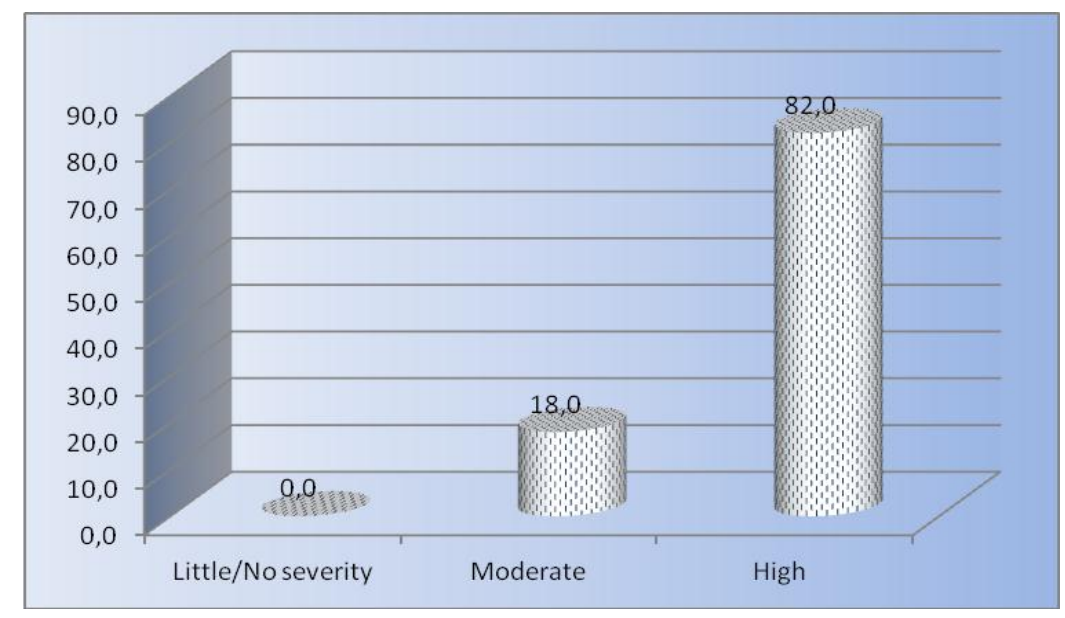

Figure (2): Frequency Distribution of Posttraumatic Stress Disorder among the Studied Patients $(\mathrm{N}=100)$.

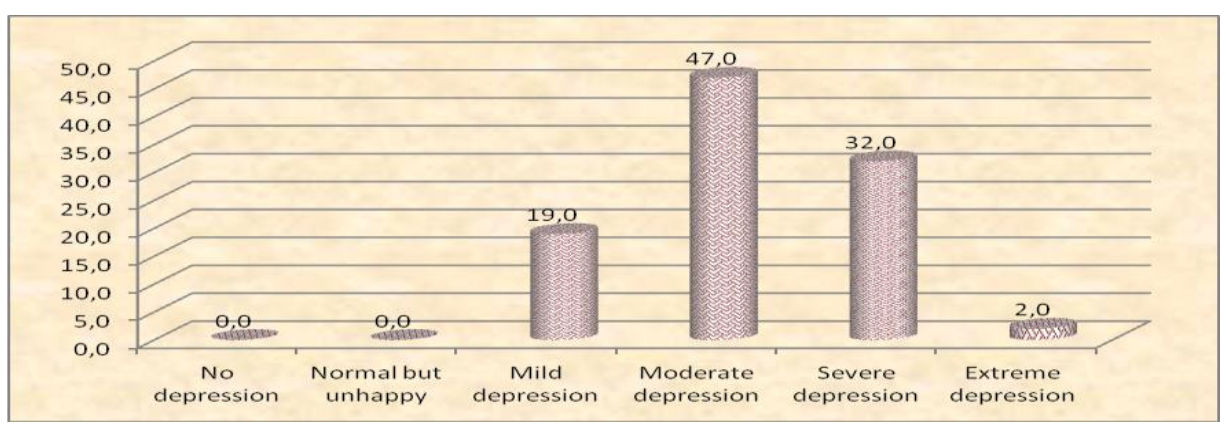

Figure (3): Frequency Distribution of Depressive Symptoms of the Studied Patients (N=100).

Table (3): Correlation between social phobia, Post-Traumatic Stress and Depression among the Studied Sample.

\begin{tabular}{|c|c|c|c|c|c|c|}
\hline & \multicolumn{2}{|c|}{ Social phobia } & \multicolumn{2}{|c|}{$\begin{array}{c}\text { Post-traumatic } \\
\text { stress } \\
\end{array}$} & \multicolumn{2}{|c|}{ Depression } \\
\hline & $\mathbf{r}$ & $\mathbf{p}$ & $\mathbf{r}$ & $\mathbf{p}$ & $\mathbf{r}$ & $\mathbf{p}$ \\
\hline \multicolumn{5}{|l|}{ Social Phobia } & \multirow{3}{*}{0.93} & \multirow{3}{*}{0.000} \\
\hline Post-Traumatic Stress & 0.91 & 0.000 & & & & \\
\hline Depression & & & 0.92 & 0.000 & & \\
\hline
\end{tabular}


Table (4):- Correlation between studied variables among the studied Sample.

\begin{tabular}{|c|c|c|c|c|c|c|c|}
\hline & & $\begin{array}{c}\text { Post } \\
\text { Traumatic }\end{array}$ & Depression & Age & $\begin{array}{c}\text { Level of } \\
\text { Education }\end{array}$ & $\begin{array}{c}\text { Degree of } \\
\text { Burn }\end{array}$ & Income \\
\hline \multirow{2}{*}{ Social Phobia } & $\mathrm{r}$ & 0.91 & 0.93 & -0.03 & -0.28 & 0.34 & -0.61 \\
\hline & p-value & $0.000 * *$ & $0.000^{* *}$ & 0.77 & $0.004 *$ & 0.000 ** & $0.000 * *$ \\
\hline \multirow{2}{*}{ Post Traumatic } & $\mathrm{r}$ & & 0.92 & 0.02 & -0.21 & 0.38 & -0.55 \\
\hline & p-value & & $0.000^{* *}$ & 0.78 & $0.02 *$ & $0.000^{* * *}$ & $0.000 * *$ \\
\hline \multirow{2}{*}{ Depression } & $\mathrm{r}$ & & & 0.026 & -0.23 & 0.40 & -0.55 \\
\hline & p-value & & & 0.80 & $0.02 *$ & $0.000^{* *}$ & $0.000^{* *}$ \\
\hline \multirow{2}{*}{ Age } & $\mathrm{r}$ & & & & 0.60 & -0.11 & 0.13 \\
\hline & p-value & & & & $0.000^{* *}$ & 0.23 & 0.18 \\
\hline \multirow{2}{*}{$\begin{array}{c}\text { Level of } \\
\text { education }\end{array}$} & $\mathrm{r}$ & & & & & -0.24 & 0.30 \\
\hline & p-value & & & & & $0.016^{*}$ & $0.002 *$ \\
\hline
\end{tabular}

\section{Discussion:-}

During adolescence, adolescent females develop a stronger recognition of their own personal identity including a set of personal moral and values and greater perception feeling of self-worth. An increased awareness of body shape and image is a fundamental psychosocial task during adolescence. Any dramatic changes in body size and shape can cause a great ambivalence among them Chu et al., (2018). Burn injuries are defined as injuries that caused by the application of chemicals, heat, electrical current or radiation to the external or internal surface of the body, which causes destruction of the tissue. Burns are painful experience and devastating forms of trauma which affect physical, psychological and social health of the victims as physical disability, scars, deformities, depression, posttraumatic stress disorder and social anxiety disorder Jain et al., (2017).

Therefore, the present study aimed to investigate psychological problems among adolescent females with burn.

The current study revealed that all of the adolescent females' burn patients' age ranged between 13-19 years old with the mean age $15.8 \pm 1.84$. This might be due to lack of knowledge and awareness regarding risk factor of burn and its prevention. This result was consistent with the finding of several research studies as those of Tillman\& Prazak, (2018) who found that, the majority of adolescent females age with traumatic events of burn injury ranged between 14-18 years old. This result was in the same line with Elsayed et al., (2018) who found that, the mean age of 
adolescent females with burn was $15.32 \pm 2.85$ years old. On the other hand, this result was inconsistent with Lama et al., (2015) who reported that, the majority females' age was ranged from 21-30 years old.

As regards to level of education the current study showed that more than one quarter were read and write, this might be due to low socioeconomic status. Another explanation are mostly of the sample lived in rural areas where still education of females is not seen important., moreover, the noneducated on the lower level of education made them more prone to be either victims of accidents. This study was consistent with Panda et al., (2018) who found that, one third of adolescent female with burn were illiterate, followed by a less percentage of read and write. This result was in the same line with Echevarria et al., (2016) who found that, more than one third were primary educated. This might be due to low income and education were highly correlated, a conflicting result was found by Shahid et al., (2018) which generated that above half of adolescent females with burn were secondary school education., this might be due to cultural differences or differences in the place of data collection.

Concerning working status, the current study revealed that more than two thirds were not working, this could be due to that the higher percentage of female burn patients in the current study were low in education, as female patients with low education have few opportunities to find a job, another explanation this result might be due to their young age. This result was in agreement with Singh, (2017) who found that, more than two thirds of the of adolescent females with burn were not working and found a strong relationship between educational level, low income, nonemployment and mental illness. In addition to Elsayed et al., (2018) who found that about three quarter among adolescent females were not working and reported that unemployment was one of the a socio-demographic variable among them.

Regarding family income, the current study revealed that, half of adolescent females with burn had low family income, this could be due to non-employment where the higher percentage were either illiterate or only with basic education, thus had fewer opportunities for working. . This result was in agreement with Winanda et al., (2018) who reported that, around half of adolescent females with burn had low family income. On the other hand, this result was conformity with the study done by Fauerbach et al., (2016) who found that, more than two thirds of adolescent females with burn were employed as a strong correlation between employment and income, so they have good family income. Also, according to Shahid et al., (2018) who found that, more than two thirds of adolescent females with burn had good income.

Regarding the cause of burn, the current study revealed that, more than two thirds of the cause of burn were fire-flame, this could be due to that females were responsible for daily household activities as cooking that increase the risk for fires due to the use of open fire for cooking, wearing loose clothes. In addition, the poorly ventilated areas were they keep the gas cylinders or buns that could lead to accidents. Moreover, as girls of the studied sample were 
not well educated, thus less careful and were accidental prone. This finding was consistent with Karki et al., (2018) who found that, more than two thirds of the causes of burn were due to fir-flame among adolescent females. In addition, this result was at the same line with Shankar et al., (2014) and Patil\&Parmar (2016) who found that, the majority of the causes of burn was fire-flame. On the other hand, this result was inconsistent with Pande\&Ishak, (2017) who reported that, the majority of the cause of burn among adolescent females was hot liquids.

The current study revealed that, strongly no suicidal attempts were involved as this was one of the leading causes of attempts in adolescent females, may be due to mandatory police report to any suicidal case and thus the year of scandal so they don't report or admitted that the burns was due to suicide. All the circumstances among adolescent females with burn were accident, This might be due to, lack of knowledge about home accidents as accidental fires, hot appliances such as an oven or scald injuries that result from hot liquids, pressurized equipment that contain hot gases or stream, chemical burn and fires that caused by faulty wiring in house. This result was inconformity with the study that done by Maske\& Deshmukh, (2016) who found that, more than two thirds of the circumstances of burn among adolescent females with burn are accidents. This result was at the same line with Dries\&Marini, (2017) who found that, the majority of burn injuries were accidents. On the other hand, this study disagreed with Tiwari et al., (2018) who revealed that, the majority of burn among adolescent females were suicidal.
Regarding degree of burn, the present study revealed that, more than two thirds of adolescent females had third degree of burn. This might be due to the high percentage of burn injury were from fire-flame accidents that lead to destruction in almost all layers of skin contain epidermis and dermis and subcutaneous tissue. This result was consistent with the study done by Wissman et al., (2017) who found that the majority of burn injuries were third degree of burn. On the other hand, this result was in disagreement with Kamboj et al., (2014) who found that, more than two thirds of burn injuries among adolescent females were second degree of burn.

Concerning burn rate, the current study result showed that more than two fifth of adolescent females with burn had moderate of burn, this could be due to that almost of body surface in the current study was affected that lead to increase the probability of body surface burn rate. This study was in agreement with Weissman et al., (2017). Who found that, more than two thirds of burn rate are moderate. This result was at the same line with Yolcu et al., (2013) who found that, above half of burn rate are moderate. On the other hand, this result was in disagreement with Soundarapandiyan et al., (2017) who found that, the majority of burn rate are mild.

The current study revealed that, about one third of studied sample had sever degree and mild degree of social phobia and more than one quarter of them had moderate degree of social phobia. This might be due to fear of being judged by other people in social situations. In addition to their appearance after burn affecting normal daily life and stigmatizing behaviors. This result was in 


\section{Assessment of Psychological Problems among Adolescent Females with Burn}

agreement with Jain et al., (2017) who found that, above half of female burn patients had mild social anxiety, more than tenth had sever social anxiety and more than one third had moderate social anxiety. This result also was consistent with Arif\&Ramprasad (2013) who found that more than one quarter of female burn patients had mild social anxiety, more than one third had sever social anxiety and around one quarter had moderate social anxiety.

The present study showed that the majority of the studied sample had high level of posttraumatic stress disorder, while less than one fifth had moderate degree of posttraumatic stress disorder. This result might be due to the physical and psychological effects after exposure to painful and stressful burn injury. Also, posttraumatic stress disorder may arise as result of psychosocial process as burn victims may compare their physical appearance with the others; they grieve over the loss of their appearance. In addition to posttraumatic stress disorder may arise among females with burn related to extreme pain after burn and remembering the traumatic event that lead to development of several psychological distresses. This result was consistent with Waqas et al., (2018) who found that, around three quarters of females with burn had posttraumatic stress disorder. Also, this result was agreement with the study that done by Mclean et al., (2017) who found that, the majority of female burn patients had high levels of posttraumatic stress disorder.

The current study showed that near to half of the studied sample had moderate degree of depression, nearly one third of them had sever degree of depression and about fifth had mild depression. This result might be due to fear of separation and loss of loved one. Also, depression related to pain, physical disability, presence of scars, deformities in the body parts. The study was consistent with Swwamae, (2015) who found that around half had moderate depression, around one third had severe depression and tenth had mild depression. Also, another study done by Arif\&Ramprasad (2013) who found that more than one third of female burn patients had mild, moderate and severe depression.

The current study revealed that, there was positive significant correlation between social phobia and both of depression and posttraumatic stress disorder. Also, there was positive correlation between depression and posttraumatic stress disorder This meant that when social phobia increased, levels of depression and posttraumatic stress disorder increased. Also, when depression among adolescent females with burn increased, levels of posttraumatic stress disorder increased. This means that any increasing of one of psychological problems lead to development of another as each one influenced by others and highly correlated. This result was consistent with Jiang et al., (2018) who found that, there was positive correlation between depression and posttraumatic stress disorder and also, found that there was positive correlation between social phobia and both of depression and posttraumatic stress disorder.

The current study revealed that, there was positive significant correlation between degree of burn and both of social phobia posttraumatic stress disorder and depression, while there was negative correlation between 
social phobia and both of level of education and income. This meant when degree of burn increased social phobia, posttraumatic stress disorder and depression increased., on the other hand social phobia increased when level of education and income decreased. This result was in agreement with Jain et al., (2017) who found that, there was positive significant correlation between social phobia and both of depression, posttraumatic stress disorder and degree of burn. Also, this result was consistent with Ruth\&Vimala(2017) who found that, there was negative correlation between social phobia and both of level of education and income.

As well as, the current study, showed that there was positive significant correlation between depression and degree of burn but there was negative significant correlation between depression and level of education and income. This means that depression increased with degree of burn. On the other hand, depression increased when level of education and income decreased. This result was in agreement with Ruth\&Vimala (2017) who found that, there was positive significant correlation between depression and degree of burn, also reported that there was negative significant correlation between depression and both of level of education and income.

Moreover, the current study revealed that there was positive significant correlation between level of education and income, while there was negative significant correlation between level of education and degree of burn. This meant that level of education increased when income increased, on the other hand, the higher level of education the lower degree of burn. This study was consistent with He et al., (2017) who found that there was positive significant correlation between level of education and income. Also found that there was negative significant correlation between level of education and degree of burn, also showed that the higher level of education the lower risk for severity of degree of burn and non- fatal burn injury.

\section{Conclusion:}

From the result of the present study, one can conclude that there were positive significant correlations between degree and complication of burn with both of social phobia, posttraumatic stress disorder and depression. There is negative significant correlation between level of education and degree of burn.

\section{Recommendations:}

Based on the finding and conclusions of this study, the following recommendations are suggested:-

For burn patients:-

1- More attention should be paid to teach burn patients how to cope with stress through using stress management technique, problem solving skills and assertiveness to manage psychological effects that result from burn injury in a constructive way.

2- Post burn program through multidisciplinary team should be initiated after discharge in order to provide education, support, and prevention of complications and motivation of burn patients.

\section{For nurses:-}

3- Psychiatric nurses, Social workers and psychotherapists should be members of health team to provide health education and counseling for burn patients, their families and health team.

\section{For community:-}

4-First aids and how to save life and decrease severity of burn and complication of burn should be taught for all public through mass media 


\section{For research:-}

5- Further study should be conducted on a large number of cases at other setting in order to generalize the results

\section{References:-}

Agbenorku, P., Akpaloo, J., Aboah, K., Klutsey, E., Hoyte-Williams, P., Farhat, B., \& Hussey, R. (2016). Chemical burn injury in Kumasi: the trend and complications following and their management. Plastic and Reconstructive Surgery Global Open, 3 (10).

Akarsu, S., Durmuş, M., Yapici, A. K., Oznur, T., \& Oztürk, S. (2017). Psychiatric Assessment and Rehabilitation of Burn Patients. Turkish Journal of PLASTIC Surgery, 25(1) 2027.

American Psychiatric Association. (2013). Diagostic and Statistical Manual of Mental Disorder (DSM-5). American Psychiatric Pub. Available at https://www.psychiatry.org (Accessed 19/11/2017 at 9:00 p.m).

Arif, M., \& Ramprasad, K. (2013). Prevalence of anxiety and depression in burns patients in a tertiary care hospital. Religion (a), IOSR Journal of Dental and Medical Sciences, 26,74 .

Burns, J. (2016). Yoga for PostTraumatic Stress Disorder in Women. School of Physician Assistant Studies. Pp 589.

https://commons.pacificu.edu/pa.

Chu, X., Fan, C., Liu, Q., \& Zhou, Z. (2018). Cyberbullying victimization and symptoms of depression and anxiety among Chinese adolescents: Examining hopelessness as a mediator and self-compassion as a moderator. Computers in Human Behavior, 86, 377-386.
Connor, K., Davidson, J. Churchill, L., Sherwood, A., Weisler, R. \& FOA, E. (2000). Psychometric properties of the social phobia inventory (SPIN). The British Journal of psychiatry, 176(4), 379-386.

David, B. (1989). Burns depression checklist taken from the feeling good hand book. Using the new mood therapy in everyday life. Available at htttp//healingheartscc.com/docs/first steps/FS DepressionQuiz.pdf (Accessed 10/11/2017 p.m).

Din, S., Shah, M., Jamal, H., \& Bilal, M. (2015). Rehabilitation and social adjustment of people with burns in society. Burns, 41 (1), 106-109.

Dries, D., \& Marini, J. (2017). Management of critical burn injuries: recent developments. The Korean Journal of Critical Care Medicine, 32(1), 9-21.

Echevarría-Guanilo, M., Gonçalves, N., Farina, J., \& Rossi, L. (2016). Assessment of health-related quality of life in the first year after burn. Escola Anna Nery, 20(1), 155-166.

Elsayed, Y., Mohamed, N., Abd El-Aziz, E. (2018). Future anxiety and its relation to the body image and self-concept among adolesents with burn injury, Journal of Nursing and Health Science V (7), pp 24- 33 www.iosrjournals.org

Fathy, R. (2014). The effect of an educational program of burned patients in their quality of life, 5(1), 30 .

Fauerbach, J., McKibben, J., Bienvenu, $O$. J., Magyar-Russell, G., Smith, M., Holavanahalli, R., \& Lezotte, D. (2016). Psychological distress after major burn injury. Psychosomatic Medicine, 69(5), 473. 
He, S., Alonge, O., Agrawal, P., Sharmin, S., Islam, I., Mashreky, S., \& Arifeen, S. (2017). Epidemiology of burns in rural Bangladesh: An update. International journal of environmental research and public health, 14(4), 381.

Heeren, A., Lange, W., Philippot, P., \& Wong, Q. (2014). Biased cognitions and social anxiety: building a global framework for integrating cognitive, behavioral, and neural processes. Frontiers in human neuroscience, 8, 538.

Hoffmann, S., \& Warschburger, P. (2018). Patterns of body image concerns in adolescence and early adulthood: A latent profile analysis. Eating behaviors, 29, 28-34.

Jain, M., Khadilkar, N., \& De Sousa, A. (2017). Burn-related factors affecting anxiety, depression and self-esteem in burn patients: an exploratory study. Annals of burns and fire disasters, 30(1), 30.

Jiang, D., Jiang, S., Gong, F., Yuan, F., Zhao, P., He, X., \& Chu, X. (2018). Correlation between depression, posttraumatic stress disorder, and inflammatory factors in patients with severe burn injury. The American Surgeon, 84(8), 1350-1354.

Kamboj, A., Kukreti, P., Garg, A., \& Jhirwal, O. (2014). Free Papers (Oral). effectiveness of antipsychotics (haloperidol, olanzapine and risperidone) in patients with admitted to medical and surgical wards.Indian $\mathbf{J}$ Psychiatry, 56, S19.

Karki, B., Rai, S., Nakarmi, K., Basnet, S., Magar, M., Nagarkoti, K. Thapa, S. (2018). Clinical epidemiology of acute burn injuries at Nepal Cleft and Burn Centre, Kathmandu, Nepal. Annals of plastic surgery, 80(3), S95S97.
Lama, B., Duke, J., Sharma, N., Thapa, B., Dahal, P., Bariya, N., \& Wallace, H. (2015). Intentional burns in Nepal: A comparative study. Burns, 41(6), 1306-1314.

Manzoor, A., Khan, A., Gania, A., Suhaff, A. \& Baidya, K. (2016). Comorbid psychiatric disorders in burn patients? A tertiary care hospital based study. J Inf Res Rev, 3, 23.

Maske, A,. \& Deshmukh, S. (2016). Clinicoepidemiological study of burns: our experience with 500 patients. International Surgery Journal, 3(3), 1234-1239.

McLean, L., Chen, R., Kwiet, J., Streimer, J., Vandervord, J., \& Kornhaber, R. (2017). A clinical update on posttraumatic stress disorder in burn injury survivors. Australasian psychiatry, 25(4), 348-350.

Panda, S., Mohapatra, M., Jena, U. K., Kar, P. Sarangi, A., Jena, S., \& Sarangi, A. (2018). An epidemiological study of burn cases admitted to a tertiary care centre of Odisha. International Journal Of Community Medicine And Public Health, 5(2), 616-619.

Pande, K. \& Ishak, H. (2017). Epidemiology of burns in a major referral hospital in Brunei Darussalam. Singapore medical journal, 53(2), 121.

Patil, S. \& Parmar, D. (2016). Mortality Associated with Burn Injuries: An Observational Cross Sectional Study from Latur, Maharashtra. National Journal of Community Medicine,7 (2), 121-124.

Ruth,V. \& Vimala, G. (2017). Effectiveness of Psycho Educative Intervention on Psychological Problems among Burn Patients Admitted At Pravara Rural Hospital, Loni available at (www.ijhsr.org). 
Shahid, F., Ismail, M., \& Khan, S. (2018). Assessment of quality of life in post burn survivors: A cross-sectional single-center first validation study from Pakistan. Burns Open, 2(1), 35-42.

Shankar, G., Naik, V., \& Powar, R. (2014). Epidemiolgical study of burn injuries admitted in two hospitals of north Karnataka. Indian journal of community medicine: official publication of Indian Association of Preventive \& Social Medicine, 35(4), 509.

Singh, A. (2017). Epidemiology of Burn and Factors Influencing Mortality in Burn Patients in India. Children, 5, 3-73.

Soundarapandiyan, R., Periyasamy, P., \& Udhayasankar, V. (2017). Epidemiology and outcomes of burns patients admitted in a district tertiary care Centre, Vellore mortality, pp 1, 2.

Statistical Department of Burn. (2017). Admitted burn patients at Benha Teaching Hospital Depatment of Burn, November in the year of 2015, 2016 and 2017.

Swwamae, s. (2015). The Prevalence Of Depression Among Patients With Burns Admitted At Kenyatta National Hospital. Available at (http://psychology.uonbi.ac.ke)

Tillman, K., \& Prazak, M. (2018). Trauma in Forensic Adolescent Females: Predictors, Correlates and Mental Health Outcomes. Journal of Child \& Adolescent Trauma, 1-9.

Tiwari, P., Kavitha, T., Kamath, R., D'Souza, B., Roja, V., \& Kamath, S. (2018). epidemiology of burn Injuries in a tertiary Care teaching Hospital in south India. Indian Journal of Forensic Medicine \& Toxicology, 12(4), 206-209.

Waqas, A., Raza, N., Zahid, T., Rehman, A., Hamid, T., Hanif, A.and Chaudhry, M. A.
(2018). Predictors of post-traumatic stress disorder among burn patients in Pakistan: The role of reconstructive surgery in post-burn psychosocial adjustment. Burns, 44(3), 620625.

Waqas, A., Raza, N., Zahid, T., Rehman, A., Hamid, T., Hanif, A., ... \& Chaudhry, M. A. (2018). Predictors of post-traumatic stress disorder among burn patients in Pakistan: The role of reconstructive surgery in post-burn psychosocial adjustment. Burns, 44(3), 620625.

Weathers, F., Litz, B., Herman, D., Huska, J., \& Keane, T. (1994). PTSD checklistcivilian version (PCL-C). Bosten ,National Center for PTSD pp 50-60.

Weissman, O., Wagman, Y., Givon, A., Radomislensky, I., Peleg, K., Stavrou, D., \& Tessone, A. (2017). Examination of the life expectancy of patients with burns over $20 \%$ of their total body surface area in comparison to the rest of the population. Journal of Burn Care \& Research, 38(6), e906-e912. (pp. 248-258). Neuroscience, Psychiatry, University Hospital, p 56. Available at https://uu.diva

Wiechman, S., Kalpakjian, C., \& Johnson, K. (2016). Measuring depression in adults with burn injury: a systematic review. Journal of Burn Care\& Research, 37 (5), e415-e426.

Winanda, R., Kusumadewi, I., Wardhana, A., Wiguna, T., \& Raharjanti, N. (2018). The association between psychopathology and quality of life in burn patients,A T D R. CIPTO MANGUNKUSUMO

HOSPITAL, JAKARTA.. Journal Plastik Rekonstruksi, 4(2), 105-112

Yolcu, S., Beceren, N., Timuçin, H., \& Uludă̆, U. (2013). Emergency service admissions of patients with burn injury. J Clin Exp Invest www. jceionline. org Vol, 4(3). 


\section{تقييم المشاكل النفسية بين المراهقات المصابات بالحروق}

\section{أسماء عبدالرحمن صادقـ معالي ابراهيم المالكيـ شويكار توفيق البكري- سماح رمضان ابراهيم}

تعتبر الحروق من الأشكال الحادة التي لا يمكن التنبؤ بها حيث تؤثر على كل من الصحة الجسدية والنفسية للإنات المر اهقات المصابات بالحروق كنوع من القلق الاجتماعي والاكتئاب و اضطر اب ما بعد الصدمة. وهدفت هذه الدراسة الى استكثاف المشكلات النفسية بين المراهقات المصابات بالحروق. حيث اجريت الدراسة فى وحدة الحروق بمستشفى بنها التعليمي في مدينة بنهاعلى عينة مكونة من 100 من المر اهقات اللائي تم قبولهن بوحدة الحروق وقد خلصت الدراسة الى وجود أثز سلبي كبير للحرق على الحالة النفسية للمراهقات الإناث بالاضافة الي وجود ارتباط إيجابي كبير بين كلا من الرهاب الاجتماعي و الاكتئاب مع حدوث اضطر ابات ما بعد الصدمة ، وكذلك كان هناك ارتباط كبير إيجابي بين الاكتئاب والرهاب الاجتماعي. كما أوصت الاراسة بضرورة تركيز برنامج التدخل التمريضي التربوي النفسي على تقنية إدارة الإجهاد ومهار ات حل المشكلات و التأكيد على جميع مرضى الحروق لمساعدتهم على إدارة الآثار النفسية التي تتجم عن إصابة الحروق بطريقة بناءة. 